\title{
Social Female Adaptation / Resocialization in the Russian Reality
}

\section{Adaptación / resocialización social femenina en la realidad rusa}

\author{
Riyaz Gataullovich Minzaripov \\ Kazan Federal University, Kazan, Russia \\ ORCID: 0000-0002-5809-4391 \\ Artur Rinatovich Abutalipov \\ Kazan national research technological university, Kazan, Russia \\ ORCID: 0000-0003-2616-2481 \\ Natalia Alexandrovna Zakharova \\ Kazan Federal University Kazan, Russia \\ ORCID: 0000-0002-0606-0835

\section{Sergei Dmitrievich Karakozov} \\ Moscow Region State University, Moscow, Russia \\ ORCID: 0000-0001-8151-8108 Moscow Region State University, Moscow, Russia
}

Received 09-08-20 Revised 10-10-20

* Correspondence

Email: avfach@mail.ru
Accepted 12-11-21 On line 03-04-21

\section{Citation:}

Riyaz Gataullovich Minzaripov, Artur Rinatovich Abutalipov, Natalia Alexandrovna Zakharova, Sergei Dmitrievich Karakozov. (2021). Social Female Adaptation / Resocialization in the Russian Reality. Propósitos y Representaciones, 9(SPE2), e1083. http://dx.doi.org/10.20511/pyr2021.v9nSPE2.1083 


\begin{abstract}
Adaptation to the conditions of freedom and the resocialization of persons who served their terms is determined by a gender factor, especially in societies with a bright masculine characteristic, to which the Russian society belongs too. In such societies, the process of female post-penitentiary adaptation is more complicated, because it, as before, is dominated by a more negative attitude to female crime than to male one. This is a reflection of the specifics of a society of a masculine type, where the system of double standards influences public consciousness and determines the attitude towards persons who broke the law depending on their gender. Thus, the post-penitentiary female resocialization in Russia occurs under the influence of a combination of factors and difficulties that are typical for this period of women's lifetime, typical of ex-prisoners in Russia and connected with a specific attitude of the society to female crime as well. This situation, in many respects, determines an unsuccessful scenario of the process of post-penitentiary female resocialization and, as a result, increases risks of recurrent crime in the female environment in the modern Russian society
\end{abstract}

Key words: penitentiary system, post-penitentiary system, resocialization, ex-prisoners, social adaptation, female crime, recurrent criminality

\title{
Resumen
}

La adaptación a las condiciones de libertad y la resocialización de las personas que cumplieron sus mandatos está determinada por un factor de género, especialmente en sociedades con una característica masculina brillante, a la que también pertenece la sociedad rusa. En tales sociedades, el proceso de adaptación post-penitenciaria femenina es más complicado, porque, como antes, está dominado por una actitud más negativa hacia el crimen femenino que hacia el masculino. Esto es un reflejo de las especificidades de una sociedad de tipo masculino, donde el sistema de doble rasero influye en la conciencia pública y determina la actitud hacia las personas que violaron la ley según su género. Así, la resocialización femenina pospenitenciaria en Rusia se produce bajo la influencia de una combinación de factores y dificultades típicas de este período de la vida de las mujeres, típicas de las ex presidiarias en Rusia y relacionadas con una actitud específica de la sociedad hacia la delincuencia femenina. también. Esta situación, en muchos aspectos, determina un escenario fallido del proceso de resocialización femenina pospenitenciaria y, como resultado, aumenta los riesgos de delincuencia recurrente en el entorno femenino en la sociedad rusa moderna.

Palabras clave: sistema penitenciario, sistema post-penitenciario, resocialización, ex presos, adaptación social, delincuencia femenina, criminalidad recurrente

\section{Introducion}

Having been released from places of deprivation of liberty, ex-prisoners face lots of problems in the process of their adaptation to life in the regulatory space as they are not capable to live on their own, both in the domestic and moral sense. While being in places of deprivation of liberty, convicts tend to lose their professional skills, but acquire chronic diseases, a feeling of aggression, a sense of lost communication with the outside world, uselessness, despair, etc., which make their adaptation to the post-prison period of their life and integration into the "free" society much more complicated. The lifestyle of a person in the penitentiary system is totally different from the outside life, so, having served a term, former convicts can hardly adapt to new reality where they are usually perceived like "strangers".

The problem of post-prison adaptation, probably like any social problem, is characterized by its gender specificity. It is relevant due to the necessity for a deep sociological analysis of possibilities and prospects of crime prevention, recidivism as well, in the context of its positive dynamics in Russia. 
A high level of illegal behavior, which is, according to M.Y. Popov, a social vice of the Russian society with its traditionally nihilistic attitude to authorities (Popov, 2014). It undermines the foundations of the state's social security, threatens the well-being of every citizen and testifies to the spiritual ill-being of the Russian society. In the works of some national scientists, this disadvantage is assessed extremely toughly, but quite fairly (Alizhanova, 2015; Antipov \& Pervozvansky, 2013; Vasilchenko, 2009; Zhilko, 2012).

Omelchenko E.L., Sinkov D.V., Starostin A.M., Samygin S.I. and Vereshchagina A.V. describe the spiritual de-evolution of the Russian society in their work (Omelchenko \& Sabirova, 2012; Samygin et al., 2016; Semchenko, 2007; Sinkov, 2011; Starostin et al., 2015; Izmailova, 2014). The attitude to law, especially among young people, and the level of crime in the society as well are the most important criteria for the public welfare and state security. To know about the characteristics of a person's criminal behavior, its sources, motives and peculiarities of prevention crime in various social groups is extremely important in order to solve crime prevention problems.

In this article, we will highlight the gender-specific issue of the resocialization process of persons who served terms of imprisonment, focus on women whose adaptation to life in the postprison period has its own peculiarities. Sociological studies on the problem of post-prison adaptation and resocialization of persons who served terms of imprisonment in places of deprivation of liberty are logically related to the problems of their prison re-socialization, in particular, when they consider such research subjects as resocialization stages of persons released from places of deprivation of liberty, design of this process, preparation of convicts for release, problems of recidivism as a result of maladaptation in the post-prison period, etc.

Recently, there have also been sociological works developing relevant and insufficiently studied aspects and problems of re-socialization of persons released from places of deprivation of liberty, e.g. in the field of gender specifics of the re-socialization of ex-prisoners with a focus on social adaptation and re-socialization of women released from prison. So, this issue is discussed in the works of Izmailova E.V., Silver H, Smith G, Vandebosch H, Shapar M.A. (Izmailova, 2014; Moskalev, 2012; Silver, 1995; Smith, 1997; Vandebosch, 2005).

We also studied the works on education as Fakhrutdinova A.N., Chumarova L.G., Belentsov S.I., and others (Fakhrutdinova et al., 2019; Chumarova et al., 2019; Belentsov et al., 2017; Belentsov et al., 2019; Fakhrutdinova Anastasia et al., 2017; Kulagina, 2016; Leonova, 2013; Karpushina, 2013; Kononets et al., 2005).

The gender aspects of the resocialization of persons released from places of deprivation of liberty are being studied by foreign scientists. Scientists also pay their attention to women as subjects of post-prison adaptation, to the problem of socio-psychological, professional, labor, family order that they face after serving a term.

Nevertheless, in Russian sociological literature, the issue related to the problems of the resocialization of women released from places of deprivation of liberty is still insufficiently studied, which determines the research interest in this problem and its relevance in the view of high recidivism level in Russia, including among women.

Методы (methods) he methodological basis of this study is the structural-activity paradigm based on recognition as the central category of social subjectivity, which is the key to assessing the effectiveness of the resocialization process of people released from prison and adapting to a new reality after a period of social isolation. Consequently, the social subjectivity of a person released from places of deprivation of liberty is considered as their readiness and ability to live on their own in the society in accordance with some social norms and values adopted in it. The process of resocialization of a person released from prison is interpreted as the restoration (or acquisition) of the social status as a full member of society, ready and capable of independent life in the society based on the generally accepted system of legal and social norms. The author's interpretation of the post-penitentiary system is seen as the order established in society and regime 
for the integration of persons released from places of deprivation of liberty into a system of social ties and relations based on resocialization.

\section{The results used in the article}

1. The author's sociological study "Resocialization and social adaptation of persons released from places of deprivation of liberty in the terms of the Russian post-penitentiary system", conducted in the Republic of Tatarstan and the Kirov region of the Russian Federation in 2018 by the method of questioning among ex-prisoners (the total number of respondents was 287 people) and experts in the field of the problems under study (174 people took part in the expert survey).

2. The pilot-type study, in which people released from places of deprivation of liberty took part, was conducted in the cities of the Republic of Tatarstan, such as Kazan $(\mathrm{N}=87)$, Naberezhnye Chelny $(\mathrm{N}=49)$, Elabuga $(\mathrm{N}=34)$, Nizhnekamsk $(\mathrm{N}=26)$, Zelenodolsk $(\mathrm{N}=27)$, Zainsk $(\mathrm{N}=16)$, Bugulma $(\mathrm{N}=17)$, and in the city of Kirov, the Kirov region $(\mathrm{N}=31)$. Among the respondents there were 268 men and 19 women aged 18 years to 55 and older. The majority of respondents have secondary education (152 people) and specialized secondary education (100 people).

3. An expert survey conducted in the same cities and towns. It was attended by employees of the prosecutor's office, investigative units of the Ministry of Internal Affairs, bodies of inquiry of the Ministry of Internal Affairs, the Directorate of the Federal Penitentiary Service of the Russian Federation, the Directorate of the Federal Security Service of the Russian Federation, and bailiffs. Among them: 107 men and 67 women.

\section{Results and Discussion}

In the context of gender characteristics of crime, including recidivism, it should be noted that the average age of female criminals in Russia, including recidivists, is higher than that of men. Scientists believe this is due to a number of factors of criminological, social, psychological properties that determine the differences in the criminal activity of men and women. For example, researchers associate a more mature age of recidivists among women with some features of their psychology, namely: "they perceive and suffer more from unsettled personal life, breakdown or absence of a family and other socially useful relationships, having a criminal record and limitations that result from this." Often, having lost the restraining beginnings of family and motherhood, having encountered certain life difficulties after being released from prison and not having found the necessary support from their immediate social environment, this category of female exprisoners commits crimes again, which affects the intensity of their offenses and the number of convictions .

It is worth noting the high resocialization potential of the family and family ties for the former convict, its significance is high for both men and women who have served their prison terms. So, according to the analysis carried out by N.V. Kulagina, the former convict without socially useful connections in the form of the family is more wary and hostile towards others, shows a higher level of aggressiveness and distrust of people.

For convicted women, such a factor as the family and family support means a lot, and therefore breaking family ties has an extremely negative effect on their socio-psychological state and adaptation to the conditions of freedom after release from prison. It can be assumed that this is one of the most important stimulants for their successful post-prison resocialization, and its absence significantly complicates the return of the convicted woman to normal life. According to experts, every second person out of the number of persons released from places of deprivation of liberty loses ties with the family, which negatively affects their social adaptation, but women are much more worried about this gap with the family.

The research conducted by A.N. Antipova and V.B. Pervozvansky noted that the vast majority of women after release from prison do not count on the help of state bodies and public 
organizations in the process of their adaptation to the conditions of freedom, relying entirely on family and friendship ties in this matter. At the same time, they also revealed that long-term plans of females in the post-prison period of their lives, characterized by a focus on employment, creating a family and restoring social ties, improving the level of education, are completely different from the real situation. However, as we have already noted, the reason for the social maladaptation of female ex-prisoners should be sought not only in their inability or unwillingness to return to a socially acceptable lifestyle, but also in disinclination of society to accept these women as full actors of social relations.

The study made by A.A. Hatsats among women during their post-prison adaptation showed that when being released, many of them experienced confusion, fear of the new life outside the penitentiary institution, and uncertainty that they could start an independent life. She also recorded:

- the negative dynamics of the social well-being of women released from places of deprivation of liberty, which is quite natural taking into account the conditions of detention of convicts in prisons;

- an extremely high level of pessimism among female ex-prisoners regarding prospects for their future: the vast majority of respondents in the study are convinced that they have no future.

As the main reasons, namely, adaptation barriers in the post-prison period of life of female ex-prisoners A.A. Hatsats identified those that were associated with their personal problems, difficulties of finding a job after release, interaction with law enforcement agencies and financial problems.

Scientist S.M. Alizhanova points to such a post-prison female adaptation, which is associated with the lack of their own housing as a typical problem for this category of women. At the same time, she also notes that if some women released from places of deprivation of liberty did not have a permanent place of residence even at the time of conviction, other women who were released do not want to return to their previous place of residence. So, the problem of providing female ex-prisoners with housing becomes extremely relevant, and its resolution is seen by scientists in the creation of special centers for the social adaptation of persons released from prison.

Although female recidivism is significantly inferior to male crime, research shows that it grows on average by $1.8 \%$ per year, which, according to researchers, indicates the low effectiveness of traditional measures of criminal law against this phenomenon in the Russian society, which has a difficult criminological situation, in prisons as well.

According to researchers, the significant difference between the male and female postprison adaptation is that psychological stereotypes, social connections and values of a woman sentenced to imprisonment are being destroyed faster, and the crimes committed have a much greater impact on her. As a result, she is more slowly leaving the psychological state and selffeeling of being a "criminal", is more slowly being drawn into the process of resocialization, which allowed scientists to conclude that the imprisonment affects women more negatively than men.

Therefore, the post-prison period for women is more difficult, and you need to know its gender specificity, if the task is to help women who have been released from places of deprivation of liberty successfully adapt to the new, post-prison reality.

Although our study showed that, in the ex-prisoners' opinion, the attitude towards crime in the Russian society does not depend on the sex of the person who committed the crime (Table 1), adaptation to the conditions of freedom requires great psychological efforts from them, which makes the process of post-prison resocialization to life in freedom much more complicated. 
Table 1. Attitude to male and female crime in the Russian society in the estimates of ex-prisoners,

$\%$.

\begin{tabular}{|c|c|c|c|c|}
\hline Frequency & Percentage & Valid percentage & \multicolumn{2}{|c|}{ Accumulated percentage } \\
\hline 1. female & 63 & $\mathbf{2 2 , 0}$ & 22,0 & 22,0 \\
\hline 2. male & 64 & $\mathbf{2 2 , 3}$ & 22,3 & 44,3 \\
\hline $\begin{array}{c}\text { 3.same negative attitude: } \\
\text { the sex of criminal does } \\
\text { not matter }\end{array}$ & 118 & $\mathbf{4 1 , 1}$ & 41,1 & 85,4 \\
\hline 4. cannot answer & 42 & $\mathbf{1 4 , 6}$ & 14,6 & 100,0 \\
\hline Total & 287 & $\mathbf{1 0 0 , 0}$ & 100,0 & \\
\hline
\end{tabular}

The experts interviewed in our study also believe, like most scientists working in this subject field, the attitude to female crime in the society is almost twice more negative compared to the attitude to male crime (see table 2).

Table 2. Attitude to male and female crime in the Russian society in the expert estimates, \%.

\begin{tabular}{|c|c|c|c|c|}
\hline Frequency & Percentage & Valid percentage & \multicolumn{2}{c|}{ Accumulated percentage } \\
\hline No answer & 1 & $\mathbf{6}$ &, 6 &, 6 \\
\hline 1. female & 57 & $\mathbf{3 2 , 8}$ & 32,8 & 33,3 \\
\hline 2. male & 29 & $\mathbf{1 6 , 7}$ & 16,7 & 50,0 \\
\hline $\begin{array}{c}\text { 3. same negative attitude: } \\
\text { the sex of criminal does } \\
\text { not matter }\end{array}$ & 85 & $\mathbf{4 8 , 9}$ & 48,9 & 98,9 \\
\hline 4. cannot answer & 2 & $\mathbf{1 , 1}$ & 1,1 & 100,0 \\
\hline Total & 174 & $\mathbf{1 0 0 , 0}$ & 100,0 & \\
\hline
\end{tabular}

Thus, it can be stated that the release of women who served their terms, if not supported by an effective system of measures of the economic, organizational, legal, and socio-psychological nature, becomes a source of growth for such a dangerous phenomenon as female recidivism, although it is estimated much less than male one by experts in our study (Table 3). We take into consideration the share of female and male crime in the total array of crimes in the Russian society, which determines the data in the tables below.

Table 3. Female and male recidivism in Russia according to experts, $\%$.

\begin{tabular}{|c|c|c|c|c|}
\hline Frequency & Percentage & Valid percentage & \multicolumn{2}{|c|}{ Accumulated percentage } \\
\hline 1. female & 11 & $\mathbf{6 , 3}$ & 6,3 & 6,3 \\
\hline 2. male & 148 & $\mathbf{8 5 , 1}$ & 85,1 & 91,4 \\
\hline 3. cannot answer & 15 & $\mathbf{8 , 6}$ & 8,6 & 100,0 \\
\hline Total & 174 & $\mathbf{1 0 0 , 0}$ & 100,0 & \\
\hline
\end{tabular}

As a result, the problems and contradictions that determine the process of female postprison adaptation in Russia are associated with a number of reasons, among which, first of all, there is a more negative attitude of the society to female crime than to male crime, which is a consequence of the masculine nature of society.

Socio-psychological problems and re-socialization resources of former convicts more and more often draw researchers' attention. They refer to the gender factor, which, in many respects, determines the specifics of the behavior of this category of people in conditions of both the penal and post-prison regime. At the same time, we want to highlight the opinion of researchers, according to which, psychologically, most convicted women serving sentences in prisons do not have qualities that would seriously complicate the process of crime prevention during their resocialization. Moreover, compared with male criminals, female ones have a lot fewer asocial attitudes, in the opinion of scientists, as well as persistent criminal beliefs, with the exception of repeat offenders. Moreover, scientists focus on the fact that during the preparation of convicted women for release from places of deprivation of liberty, the family and children should be taken into account, which is quite a strong motivator for the positive female post-prison adaptation, both 
who already have family status and who do not have one (in the second case we are talking about the prospects of creating a family, very significant for women).

One should take into account the fact that for all negative results of crime for the society in general, female crime is characterized by more serious social consequences, especially in the communities that still maintain the traditional central role of a mother woman in the family. For the Russian society with its cult of motherhood, the growth of female crime symbolizes the crisis of family culture and the spiritual foundations of the society as a whole. In this regard, the problem of prevention and reduction of female crime in the country is becoming especially acute, the solution of which largely depends on how effectively the problems of post-prison adaptation of convicted women will be solved.

The result of social adaptation in the post-penitentiary period depends on a number of factors, many of which are not gender-related, but, nevertheless, in the scientific community there is an opinion that it is more difficult for ex-prisoners to adapt to conditions of freedom for some reasons, among which researchers distinguish the following:

- a higher susceptibility to their "prison" past, which often determines the decision to break family ties after release in order to protect the family from shame;

- a more negative attitude of the society to female crime than to male one, which is characteristic of a masculine society where there are double standards that form different assessments of the same phenomena and actions with regard to men and women;

- a higher degree of socio-psychological changes that women have compared with men, it affects the behavior of women released from prison.

The fact is that a woman's nature being more emotional and mentally susceptible, contributes to a deeper internalization of new values, norms and attitudes, behavioral strategies that prevail in prison, which prevents her from rapid resocializing in conditions of freedom, a quick return to standards of behavior, relevant generally accepted standards. A fairly common occurrence among women released from places of deprivation of liberty is alcoholism, drug addiction, obscene language, rude, aggressive, and often vulgar behavior.

The list of reasons complicating the female post-prison adaptation of women should be extended with the fact that the family situation of convicted women is more tragic - family ties tend to break up for them to a much greater extent than for convicted men, and, it is well known, family support, both during the period of serving the sentence, and after it, is extremely important for the normal resocialization of a convict. As practice shows, for women who successfully pass the stage of primary resocialization in places of deprivation of liberty, the values of family and motherhood become more important and, under more favorable circumstances, are restored, but life strikes them hard:

- husbands get divorced from them;

- they are deprived of motherhood;

- not all of them have an opportunity to successfully solve housing problems.

\section{Summary}

Thus, in the minds of ex-convicted women in the penitentiary period of their lives, maladaptation attitudes related to the lack of vision for the future are superimposed on the real difficulties of the post-prison period, determined by difficulties of finding a job, restoring a family and family ties, integrating into the society that reluctantly hosts women with a "prison history". All those factors in combination define an unsuccessful scenario for adapting this category of women to freedom and relapse crime in the women's environment. 


\section{Conclusions}

The results of our study allow us to conclude that adaptation to conditions of freedom for persons who served their terms has its gender specificity, which is mostly seen in masculine-type societies. The modern Russian society also belongs to this type of society, despite quite bright tendencies of its feminization. The analysis of problems and contradictions that determine the process of female post-prison adaptation in Russia showed that this process is more complicated for them than for men for a number of reasons, among which the more negative attitude of the society to female crime than to male one is dominant. This reflects the specifics of a masculine-type society in which the action of double standards (what is forgiven to men is unacceptable to women) continues to influence social consciousness and development. Together with typical difficulties of the postprison period for ex-prisoners in Russia, related to the problems of their employment, restoration or establishment of family and family ties, integration into the society reluctant to accept people with a "prison history", an unsuccessful scenario of the resocialization of women released from prison is formed, and, as a result, increases risks of recidivism for women.

Female crime, despite its relatively low share in the structure of crime, is one of the acute social problems that adversely affects demography, family well-being, and spiritual and moral development of youth, which, in general, poses a threat to the social security of the society. And the systemic crisis that the Russian society experienced at the beginning of the 1990s made this situation much worse, as evidenced by the results of both the author's sociological research and other studies conducted by foreign and national scientists that are used in this article. They testify that the successful adaptation of women released from places of deprivation of liberty depends on numerous factors related to both the readiness of the state and society to effectively participate in their integration into life in the legal space, and their assistance in correction during the period of serving their sentence in places of imprisonment. The fact that the resocialization of women is a complex process was totally proved in the course of the study, the results of which indicate the need for an integrated approach to this problem, involving, inter alia, the study of the sources of female crime, and in the future - the preparation of theoretical approaches to crime prevention.

\section{acknowledgements}

The work is performed according to the Russian Government Program of Competitive Growth of Kazan Federal University.

\section{References}

Alizhanova, S.M. (2015). Social control over women released from prison Bulletin of the Saratov State Law Academy, 1(102), 193-199.

Antipov, A.N., \& Pervozvansky, V.B. (2013). Criminological characteristics of convicted women. Criminological journal of the Baikal State University of Economics and Law, 1, 41-49.

Belentsov, S.I., Fahrutdinova, A.V., \& Okulich-Kazarin, V. (2017). Education of civic consciousness in George Kershenshteyner's creativity. European Journal of Contemporary Education, 6(1), 5-13.

Belentsov, S.I., Fahrutdinova, A.V., \& Grevtseva, G.Y. (2019). Free education: Fundamentals of humanistic pedagogics (on the example of activity of the German public figures of the second half of XIX - the beginning of the XX centuries of F. Gansberg, L. Gurlitt, G. Sharrelman). European Journal of Contemporary Education, 8(1), 201-207.

Chumarova, L.G., Vinnikova, M.N., \& Fakhrutdinova, A.V. (2019). Theological and educational ideas of the Tatar enlightener Kayum Nasyri. Humanities and Social Sciences Reviews, 7(6), 89-92.

Fakhrutdinova Anastasia, V., Khayrutdinov Ramil, R., \& Gutman Eugenia, V. (2017). SocialPedagogical Support Technology for University Students: Individual Safety Context. 4th International Conference on Education, Social Sciences And Humanities (SOCIOINT 2017), 758-763. 
Fakhrutdinova, A.V., Shamsutdinova, D.V., \& Ramsiya, N.G. (2019). Paradigmatic methodology of civic culture formation process in young generation. Journal of Sociology and Social Anthropology, 10(4), 198-202.

Izmailova, E.V. (2014). Specificity of the resocialization of convicted women. Resocialization of convicts in the conditions of civil society development: a collection of materials of the International Scientific and Practical Conference (December 11-12, 2014). Kirov: FKOU DPO Kirov IPKR FSIN of Russia, 153-154

Karpushina, M.V. (2013). Recurrent crime of women released from prison, and its prevention. Abstract of Diss. ... Cand. legal sciences. Ryazan, 24 p.

Kononets, A., Trifonov, O., Kachaeva, M., \& Kachnova, N. (2005). Social, psychological and psychiatric problems of women in detention. Crime and Punishment, 3, 12-14.

Kulagina, N.V. (2016). The role of the family in the social adaptation of those who have served their sentences. Sociological Studies, 9, 147-150.

Leonova, E.Yu. (2013). Resocialization of convicts in the educational space of higher education. Fundamental research, 10(14), 3248-3251.

Moskalev, A.Yu. (2012). Personality characteristics of repeat offenders. Psychopedagogy in law enforcement, 2(49), 84-89.

Omelchenko, E.L., \& Sabirova, G.A. (2012). Return? (Post) penitentiary experience of young women. Journal of Social Policy Studies, 4, 485-504.

Popov, M.Yu. (2014). Decriminalization of modern Russia: in search of a solution to the problem. Economic and Humanitarian Studies of the Regions, 6, 60-73.

Samygin, P.S., Popov, M.Yu., \& Samygin, S.I. (2016). Attitude to law as a criterion of the effectiveness of the legal socialization of modern Russian youth. Humanitarian, socioeconomic and social sciences, 5, 51-56.

Semchenko, I.V. (2007). Designing the social adaptation of citizens released from prison: a regional aspect. Abstract of Diss. Orel.

Silver, H. (1995). Reconceptualizing Social Disadvantage: Three Paradigms of Social Exclusion. Social Exclusion: Rhetoric, Reality, Responses. Ed. by G. Rodgers, C. Gore, J. Figueiredo. - Geneva: International Institute for Labour Studies.

Sinkov, D.V. (2011). Crimes and punishments of women: analysis of current trends. Criminological journal of the Baikal State University of Economics and Law, 3, 34-41.

Smith, G. (1997). The preparation of prisoners for release. 12-th Conference of Directors of Prison Administration (CDAP). Strasburg, 26-28

Starostin, A.M., Samygin, S.I., \& Vereshchagina, A.V. (2015). From national identity to military and information security: the evolution of war and the diversity of its forms in the conditions of spiritual devolution of modern society. State and municipal government. Scientific notes of SKAGS, 4, 158-163.

Vandebosch, H. (2005). The Perceived Role of Mass Media Use during Incarceration in the Light of Prisoners' Re-entry into Society. Journal of Criminal Justice and Popular Culture, 12(2), 96-115

Vasilchenko, O.V. (2009). Social adaptation of convicts in prisons in the modern penitentiary system of Russian society. Rostov na Donu. D: Publishing House SKNTS VSH SFU, 126 p.

Zhilko, I.A. (2012). Involvement of prisoners to work as a means of preventing recurrent crime. Criminological Journal, 4, 116-120. 